\title{
Responsibilities Of The Corporate Director Against The Dark Criminal Action In The Position Based On The Decision Of The Court Sumber Of Cirebon Regency (Studies on Decision No.202 / Pid.B / 2019 / PN.Sbr)
}

\begin{abstract}
Junaidi $^{1}$, Sri Endah Wahyuningsih ${ }^{2}$ and Ira Alia Maerani ${ }^{3}$
Abstract. The problems of this study were 1) corporate position as the subject of criminal law in Indonesia? 2) law enforcement against corporations as subjects of a criminal offense of embezzlement in office at the Court Sumber of Cirebon Regency? 3) accountability of corporate directors to the crime of embezzlement in office by Court Sumber of Cirebon Regency.

The method used by researchers is sociological approach juridical law and specification in this study were included descriptive analysis. The source and types of data in this study are primary data obtained from interviews with field studies The defendant and the Legal Counsel in prisons Cirebon, And secondary data obtained from the study of literature. Data were analyzed qualitatively.

Based on the results of this study are The position of the corporation as a subject of criminal law in particular is currently only recognized in the Act governing the criminal offense outside the Criminal Code. Law enforcement has inkracht / final until a court decision with the principle of lex generalis / delict general, instead of using the principle of lex sepesialis for in the Penal Code there is no article regulating the criminal offense of corporate (Company Law) Law Company Limited of the Republic of Indonesia No. 40 of 2007 . Accountability director of the corporation against the crime of embezzlement in a position based on the decision of the Court Sumber of Cirebon Regency is from the start (LP) Police Report Number: LP B / 446 / X / 2017 / Jabar / RES CRB dated October 8, 2018 and has been decided by the Court in decision Number 202 / Pid.B / 2019 / PN Sbr.

Keywords : Responsibility; Corporate; Crime; Fraud; Position.
\end{abstract}

\section{Introduction}

Law is a combination of rules to live and coercive, containing an injunction, prohibition or permission to do or not do something, and with a view to set the order in public life. In essence, "Crime is actually a social phenomenon among the public tiring if not dealt with will cause serious adverse effects on the peace and discomfort will always haunt every citizen. Crime also shows behavior that is contrary to law, either alone or threat is real action and have consequences to property and objects, physical, even the death of a person ". 4

Corporate crime is not officially recognized as an independent field of study up Edwin Sutherland provides a definition of white collar crime in 1949. Sutherland in 1949, the American Sociological Society debate on the need to expand the boundaries of crime

\footnotetext{
1 Student of Master of Law, Universitas Islam Sultan Agung Semarang and Advocate, email: djunaedinu@gmail.com

${ }^{2}$ Lecturer of Faculty of Law, Sultan Agung Islamic University (UNISSULA), Semarang

${ }^{3}$ Lecturer of Faculty of Law, Sultan Agung Islamic University (UNISSULA), Semarang

${ }^{4}$ Romli Atmasasmitha, 1992, Teori dan Kapita Selekta Kriminologi, Bandung: Eresco, p. 5
} 
studies to enter the criminal act respectable people in their work. ${ }^{5}$ Criminal responsibility so far not regulated in the Criminal Code that corporations as subjects of law, but only set against individual legal subjects, so that officials within the corporate structure can not be dragged outside the criminal offense unless the Criminal Code, including; environmental law, tax law, corruption.etc.

Government services are generally mirrored by the performance of the government bureaucracy, the community at any time is always demanding quality public services from bureaucrats, even though the charge was not as expected, because empirically public services that occurred during the time still characterized by cumbersome, slow, expensive, and exhausting. The tendency like that happens because people still positioned as the parties to "serve" instead of being served. Serving that should be directed to the general public, sometimes reversed into a public service to the state even though the country is in fact stand for the interests of the community that built it. That is the true bureaucrat provide the best service to the community. ${ }^{6}$

Like the criminal case of embezzlement in office "committed by the accused Rini Kurnianingsih bint Oscar Sebastian, on about March 2017 until September 2018, at the Hospital Plumbon Partners, a legal entity PT. Manifestations Mulia Abadi is located at Jl. Raya Plumbon Cirebon Regency. The defendant in accordance indictment Public Prosecutor of State Attorney Sumber has proven to Crime of Article 374 of the Criminal Code, as charged in the indictment in court. By doing some cash patient into the patient's insurance / no name on a computer system that has been provided by the IT which resulted in losses in the RS. Mitra Plumbon Rp. 724,301,905.00 in 362 transactions from 355 patients, through the defendant it is done when working with attested by witnesses - the witnesses of the parties - the hospital. Plumbon Partners and Patients in the trial in accordance BAP Police Resort Sumber, filed by the Public Prosecutor Furthermore, the defendant also in doing the job by using computernumbered ID. 64. Each task for the night 2 cashier and afternoon or morning of the checkout clerk, the defendant known actions by the immediate supervisor due to demand results from patients with a receipt in full, but checked in computer no payment at the time of the date printed on the receipt. Defendant as stipulated and punishable under Article 374KUHP. Plumbon Partners and Patients in the trial in accordance BAP Police Resort Sumber, filed by the Public Prosecutor Furthermore, the defendant also in doing the job by using computer-numbered ID. 64. Each task for the night 2 cashier and afternoon or morning of the checkout clerk, the defendant known actions by the immediate supervisor due to demand results from patients with a receipt in full, but checked in computer no payment at the time of the date printed on the receipt. Defendant as stipulated and punishable under Article 374KUHP. Plumbon Partners and Patients in the trial in accordance police BAP Resort Sumber, filed by the Public Prosecutor Furthermore, the defendant also in doing the job by using computernumbered ID. 64. Each task for the night 2 cashier and afternoon or morning of the checkout clerk, the defendant known actions by the immediate supervisor due to demand results from patients with a receipt in full, but checked in computer no payment at the time of the date printed on the receipt. Defendant as stipulated and

\footnotetext{
${ }^{5} \mathrm{ibid}$

${ }^{6}$ Haafiz Jawade arsyad, 2015, Korupsi dalam prespektif HAN, Jakarta: Sinar Grafika, p. 147
} 
punishable under Article 374KUHP. Each task for the night 2 cashier and afternoon or morning of the checkout clerk, the defendant known actions by the immediate supervisor due to demand results from patients with a receipt in full, but checked in computer no payment at the time of the date printed on the receipt. Defendant as stipulated and punishable under Article 374KUHP. Each task for the night 2 cashier and afternoon or morning of the checkout clerk, the defendant known actions by the immediate supervisor due to demand results from patients with a receipt in full, but checked in computer no payment at the time of the date printed on the receipt. Defendant as stipulated and punishable under Article 374KUHP.

Based on the background of the problems that have been described, it can be used to discuss a problem as follows: How is the position of the corporation as the subject Criminal law in Indonesia? How law enforcement against corporations as subjects of a criminal offense of embezzlement in office at the Court Sumber of Cirebon Regency? How the accountability of corporate directors of the offenses of embezzlement in office by Court Sumber of Cirebon Regency?

\section{Research methods}

The method used by researchers is the law of juridical sociological approach and specification in this study were included descriptive analysis. The source and types of data in this study are primary data obtained from field studies and interviews with the accused in prisons of Cirebon. And secondary data obtained from the study of literature. Data were analyzed qualitatively.

\section{Results and Discussion}

\subsection{The Position Of The Corporation As Subjects Of Criminal Law In Current of Indonesia}

Problems corporate responsibility as a criminal is a thing that is not simple given the corporation is a legal entity. This problem stems from the principle of no punishment without fault. The fault was the attitude of the heart, which naturally only in the course of nature, and therefore, it is deemed that natural man can only be requested criminal liability. ${ }^{7}$

In the beginning, which can be regarded as a subject of criminal law by the makers of the Act is that only humans (individual). The subject of criminal law is known in Law Criminal Law (Penal Code), namely individual. Corporate thinking has not been seen as a subject of criminal law, but in its development, the corporation has been regarded as a subject of criminal law. ${ }^{8}$

Scientific study about corporate responsibility as a legal entity in committing a crime is not just a national issue, but has become a global issue, so that the arrangement and placement of the corporation as a subject of criminal law can not be denied again.

\footnotetext{
${ }^{7}$ Wangga, Maria Silvya E. Criminal Liability For Political Parties Law Firm In Corruption, Integrity Journal, 2018, Vol.4 No.2 in Corruption, Integrity Journal, 2018, Vol.4 \# 2

${ }^{8}$ Ratomi, Achmad. Corporations As Actors Crime (A Criminal Law Reform Flow Facing Globalization and Industry), Al'Adl Journal, 2018, Vol. 10 No. 1
} 
There is a global issue, the corporation used as subject criminal law motivated by history and experience that is different in each country, including in Indonesia. Development of industrialization and progress in the field of economy and trade has encouraged global thinking that the subject of criminal law is no longer confined to the natural man, but including also the corporation, due to certain criminal offenses can also be committed by a corporation. ${ }^{9}$

The position of the corporation as a subject of criminal law in particular is currently only recognized outside of the Code of Criminal Penal Code. This is because the Code of Penal Indonesia still holds the view societas delinquere non potest so as not to accommodate the position of the corporation as a subject of criminal law began at the level of the investigation as a reporting and analysis have proven their Police Report Number: LP B / 446 / X / 2017 / Jabar / RES CRB dated October 8, 2018 armed with a Power of Attorney law enforcement process is still running no heed (UU PT) law Company Limited No. 40 of 2007 regarding Limited Liability Company, that shows the position of the Criminal Code dominate legal subjects Natural Person is the reason; 1)Br. Kaerun Kasir as a reporting capacity (legal standing)concerned not the Director, in pursuing legal represent the company in and out of court, 2) Evidence of corporate losses as the injured party only print sections evidenced by Information Technology (IT) but not from the authorized public accounting or Accounting externally. 3) That at the time of the police report (LP) do not show / submit the following documents Deed of Establishment that has been registered in the Ministry of Justice and Human Rights as the validity of the "legal standing" corporation that is subject to the law (Rechtspersoon).

\subsection{As Law Enforcement Against Corporate Crime Embezzlement Subjects In Position In Court Sumber of Cirebon Regency}

In development of criminal law in Indonesia, the criminal provisions of the Criminal Code has expanded beyond the criminal, that is not limited only to humans but also to the corporation. This development is in line with the development of criminal law in other countries. ${ }^{10}$ On this basis, initially to commit a crime than a man, but with the findings of the jurisprudence (normative), the corporation recognized as a subject of criminal law (except in the Law on Banking) ${ }^{11}$,

Based on interviews with Rini Kurnianingsih, ${ }^{12}$ as the defendant / suspect in this case is over worked approximately 15 years in the hospital Mitra Plumbon be cashier routine work in money comes from patient payment at the time of curfew sums of revenue which starts at entrance to the closed curfew matched with money, then the money tied up with rubber and memorandum and receipt copies, are always stored in drawers in the room till. Rini who know that there is much less work SOP Rules of

\footnotetext{
${ }^{9}$ Results of interviews with Eko Suprijandi SH., Et al Legal Counsel (LPBH), on 13 February 2020 at 11:15 $\mathrm{pm}$

${ }^{10}$ Sutan Remy Sjahdeini, 2006, Pertanggungjawaban Pidana Korporasi, Jakarta: Grafiti Pers, p. 31-32

${ }^{11}$ JE.Sahetapy, 2011, Problematika Menciptakan Iklim Usaha yang Kondusif, Jakarta: Komisi Hukum Nasional RI, p. 6.

12 Results of interviews with Kurnianingsih Rini, as the suspect / defendant, on February 11, 2020, $13: 15$ $\mathrm{pm}$
} 
Conduct does not exist at all, by any chance this year would no accreditation then according to the boss being made everything, to qualify for hospital accreditation Mitra Plumbon.

State law enforcement policies that have a very large / wide it on command laws of the Republic of Indonesia. But we see the end of the Regency Court Sumber, because all use the legal basis for taking a foothold to be taken, although we have remedies such as appeal and cassation, remedy this we all return to the client / our principals, not necessarily do without any effort or desire (advaice remain submitted). That should be known is Legal Aid and Counseling Nah'dlatul Ulama (NU LPBH) Cirebon, provide legal assistance to the poor, and the average - average people who come to ask for help the poor and middle economic, ${ }^{13}$

Law enforcement has inkracht / final until a court decision with the principle of lex generalis / delict general, instead of using the principle of lex sepesialis for in the Penal Code there is no article regulating the criminal offense of corporate (Company Law) Law Company Limited of the Republic of Indonesia No. 40 of 2007 . Whereas the corporate losses totaling Rp. 724,301,905.00 of 362 transactions from 355 patients, the basis for the criminal acts of Article 374 of the Criminal Code starting stages of the investigation until the Regency Court's decision Sumber. Convict against the defendant are therefore by imprisonment for two (2) years and six (6) months; 1 ) the difference in juridical argumentation because when using the principle of lex generalis reasonable court decision does not specify their corporate losses, since the corporation (directors) never reported losses under the terms of applicable legislation. 2) of the fact of the trial nor raised their negligence due to not run Article 5 of Law of the Republic of Indonesia No. 8 of 2007 on Corporate Documents: make the Annual Balance Sheet, Journal Daily transactions and other rights obligations related to the company's business activities

\subsection{Accountability Corporate Director Crime Against Embezzlement In the Position of Court Sumber of Cirebon Regency}

In criminal law we have recognized that the corporation as the subject or criminal but a liability in criminal law is still ambiguous. When we look at the Code of Penal (Penal Code), which still faithfully we follow to this day, and corporate criminal act can not be captured, because the corporation does not include legal subjects or actors.

In connection with the events experienced by the defendant, as presented in the introduction above, based on the testimony of witnesses postscript employees Mitra Plumbon Hospital, in essence acknowledged that management does not function properly. That is very clear, the defendant has been conditioned as a cashier who blamed not through the mechanism Businesses Regulations, namely the absence of stage warning letters when it is considered there are omissions in the work. With all the limitations of human turns defendant exploited by parties who feel they have

\footnotetext{
${ }^{13}$ Results of interviews with Eko Suprijandi SH., Et al Legal Counsel (LPBH), on 13 February 2020 at 11:15 $\mathrm{pm}$
} 
more capabilities such matters can proceed smoothly, structured and systematic. Companies are normal and healthy. ${ }^{14}$

Accountability of corporate directors of the offenses of embezzlement in office by Court Sumber of Cirebon Regency is from the start (LP) Police Report Number: LP B / 446 / X / 2017 / Jabar / RES CRB dated October 8, 2018 and was decided by the Court in its decision No. 202 / Pid.B / 2019 / PN Sbr. That the director was never present in the agenda of the trial, and the base pedestal power of attorney granted to employees by authorizing the director to the Proxy is the head cashier, not to represent the corporation as the injured party, because the power of the director used to represent the corporation in terms of its business activities. not in terms of legal remedies as provided for in Article 98 of Act No. 40 of 2007 on Limited Liability Company, including in this case the remedy did report to the police, corporation through its director and if they will take legal actions both inside and outside the corresponding provisions of the law is to give power to the Advocate as stipulated in Act No. 18 of 2003 concerning Advocates as the most competent to represent the Corporate Director, both inside and outside the court

\section{Closing}

\subsection{Conclusion}

- The position of the corporation as a subject of criminal law in particular is currently only recognized outside of the Code of Criminal Penal Code. This is because the Code of Penal Indonesia still holds the view societas delinquere non potest so as not to accommodate the position of the corporation as a subject of criminal law began at the level of the investigation as a reporting and analysis have proven their Police Report Number: LP B / 446 / X / 2017 / Jabar / RES CRB dated October 8, 2018 armed with a Power of Attorney law enforcement process is still running no heed (UU PT) law Company Limited No. 40 of 2007 regarding Limited Liability Company, that shows the position of the Criminal Code dominate legal subjects Natural Person is the reason; 1) Br. Kaerun Kasir as a reporting capacity (legal standing)concerned not the Director, in pursuing legal represent the company in and out of court, 2) Evidence of corporate losses as the injured party only print sections evidenced by Information Technology (IT) but not from the authorized public accounting or Accounting externally. 3) That at the time of the police report (LP) do not show / submit the following documents Deed of Establishment that has been registered in the Ministry of Justice and Human Rights as the validity of the "legal standing" corporation that is subject to the law (Rechtspersoon).

- Law enforcement has inkracht / final until a court decision with the principle of lex generalis / delict general, instead of using the principle of lex sepesialis for in the Penal Code there is no article regulating the criminal offense of corporate (Company Law) Law Company Limited of the Republic of Indonesia No. 40 of 2007 . Whereas the corporate losses totaling Rp. 724,301,905.00 of 362 transactions from 355

\footnotetext{
${ }^{14}$ Results of interviews with Eko Suprijandi SH., Et al Legal Counsel (LPBH), on 13 February 2020 at 11:15 $\mathrm{pm}$
} 
patients, the basis for the criminal acts of Article 374 of the Criminal Code starting stages of the investigation until the Regency Court's decision Sumber. Convict against the defendant are therefore by imprisonment for two (2) years and six (6) months; 1 ) the difference in juridical argumentation because when using the principle of lex generalis reasonable court decision does not specify their corporate losses, since the corporation (directors) never reported losses under the terms of applicable legislation. 2) of the fact of the trial nor raised their negligence due to not run Article 5 of Law of the Republic of Indonesia No. 8 of 2007 on Corporate Documents: make the Annual Balance Sheet, Journal Daily transactions and other rights obligations related to business activities of the company.

- Accountability of corporate directors of the offenses of embezzlement in office by Court Sumber of Cirebon Regency isfrom the start (LP) Police Report Number: LP B / 446 / X / 2017 / Jabar / RES CRB dated October 8, 2018 and was decided by the Court in its decision No. 202 / Pid.B / 2019 / PN Sbr. That the director was never present in the agenda of the trial, and the base pedestal power of attorney granted to employees by authorizing the director to the Proxy is the head cashier, not to represent the corporation as the injured party, because the power of the director used to represent the corporation in terms of its business activities. not in terms of legal remedies as provided for in Article 98 of Act No. 40 of 2007 on Limited Liability Company, including in this case the remedy did report to the police, corporation through its director and if they will take legal actions both inside and outside the corresponding provisions of the law is to give power to the Advocate as stipulated in Act No. 18 of 2003 concerning Advocates as the most competent to represent the Corporate Director, both inside and outside the court.

\subsection{Suggestion}

- In criminal law enforcement process as the subject of corporate law (rechtpersoon) when a complainant to qualify as the legitimacy of reporting required to submit corporate legal standing in the form of certificate of incorporation issued by the Notary and has passed the Ministry of Justice and Human Rights.

- The need to increase the competence of the employees of the corporation to be assigned or placed should be in accordance with the education and experience of the employee. And if necessary provide training opportunities to employees who held either outside or inside the company as a form of corporate efforts to improve HR employees.

- Increased alertness of the government to provide mental changes that have been announced through print and electronic by President Joko Widodo to be immediately implemented by all stakeholders both central government and local levels, with an evaluation so that every stakeholder in charge of the agency in direct contact with the public in the service and enforcement whether public or private law, so the sooner in the handling of public complaints. 


\section{References}

[1] Ilhami Bisri, 2004, Sistem Hukum Indonesia, prinsip -prinsip \& Implementasi Hukum di Indonesia, Jakarta: Raja Grafindo Persada

[2] JE.Sahetapy, 2011, Problematika Menciptakan Iklim Usaha yang Kondusif, Jakarta: Komisi Hukum Nasional RI

[3] Haafiz Jawade arsyad, 2015, Korupsi dalam prespektif HAN, Jakarta: Sinar Grafika

[4] Muladi and Dwija Priyatna, 1991, Pertanggungjawaban Korporasi Dalam Hukum Pidana, Bandung: Sekolah Tinggi Hukum Bandung

[5] Ratomi, Achmad. Corporations As Actors Crime (A Criminal Law Reform Flow Facing Globalization and Industry), Al'Adl Journal, 2018, Vol. 10 No. 1

[6] Romli Atmasasmitha, 1992, Teori dan Kapita Selekta Kriminologi, Bandung: Eresco

[7] Setiyono, 2002, Kejahatan Korporasi, Malang: Averroes Press

[8] Sutan Remy Sjahdeini, 2006, Pertanggungjawaban Pidana Korporasi, Jakarta: Graffiti Press

[9] Wangga, Maria Silvya E. Criminal Liability For Political Parties Law Firm In Corruption, Integrity Journal, 2018, Vol.4 No.2Dalam Corruption, Integrity Journal, 2018, Vol.4 \# 2

[10] Zaenudin Ali, 2005, Sosiologi Hukum, Jakarta: Sinar Grafika 